\title{
Analisis Praktik Pengungkapan Intellectual Capital Pada Website Universitas Peraih QS-Star 2011
}

\author{
Rizky Yudhi Pratiwi \\ Program Studi Akuntansi FEB - Universitas Muhammadiyah Malang \\ Jl. Raya Tlogomas 246 Malang 65144 \\ E_mail:Rizky_Yoed@yahoo.co.id
}

\begin{abstract}
The aim of this study is to describe of intellectual capital (IC) disclosure on the website of Indonesian university. The intellectual capital was devided to three major component; human capital, structural capital, and relational capital. The component used in this study is the framework was composed by Ulum (2011) which consist of 46 items. The result shows that from 35 university's website, Airlangga University disclose 55\% component of IC. For the major of 'human capital', 'non-academic staff' was the most widely expressed by universities. While, for the major of 'struc' tural capital', item of 'infrastucture' was domonated the disclosure. And, the 'e-learning' was a favourite item to disclose by university from 'relational capital' major. The result also indicates that the extent of IC disclosure by Indonesian university still limited.
\end{abstract}

Keywords: Intellectual capital, disclosure, website.

\section{PENDAHULUAN}

Intellectual capital mulai berkembang di Indonesia semenjak munculnya PSAK 19 mengenai aset tidak berwujud (Ulum, 2009). Aset tidak berwujud merupakan aset non moneter teridentifikasi tanpa wujud fisik. Beberapa contoh dari aset tak berwujud antara lain ilmu pengetahuan dan teknologi, desain dan implementasi sistem atau proses baru, lisensi, hak kekayaan intelektual, pengetahuan mengenai pasar dan merek dagang (termasuk merek produk dan judul publisitas). Contoh umum lainya: piranti lunak komputer, hak paten, hak cipta, film, daftar pelanggan, hak pelayanan jaminan, hak memancing, kuota impor, waralaba, hubungan dengan pemasok atau pelanggan, kesetiaan pelanggan, pangsa pasar dan hak pemasaran.

Menurut Leitner (2002) universitas adalah bagian dari sistem ilmu pengetahuan, pendidikan, dan inovasi suatu bangsa dan produsen pengetahuan, Keluaran yang paling penting dihasilkan dari suatu universitas adalah pengetahuan, digabungkan dalam hasil penelitian baru, naskah publikasi dan mahasiswa berpendidikan. Sehingga sumber daya yang paling berharga dari universitas adalah penelitian yang telah mereka lakukan dan mahasiswa dengan jaringan yang mereka miliki sehubungan rutinitas atau kegiatan organisasi mereka.

Internet merupakan salah satu media informasi yang saat ini mengalami perkembangan yang sangat pesat. Sebagai media informasi, internet memberikan pelayanan secara tepat, akurat dan efisien bagi penggunanya, serta pengguna bisa mencari informasi apapun yang diinginkan. Dengan adanya perkembangan informasi teknologi (IT) ini, universitas melakukan penyebaran informasi, dan publikasi yang terdapat pada website universitas yang dikelolanya. Pemanfaatan internet bagi universitas sangat diapresiasi oleh organisasi-organisasi yang ber-

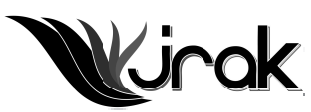

Jurnal Reviu Akuntansi dan Keuangan

ISSN: 2088-0685 Vol.2 No. 2, Oktober 2012 Pp 323-334 
Analisis

Praktik...

324 tujuan meningkatkan mutu bagi perguruan tinggi di dunia untuk menilai dan memberikan penghargaaan terhadap renking web, seperti webometrics, 4 International Colleges \& Universities (4icu), dan QS-Star.

Untuk mencapai tujuan-tujuan srategis dari universitas diperlukan pengembangan model-model knowledge management dan intellectual capital (Zurnali, 2008). IC memegang peranan penting dalam fungsi semua organisasi nirlaba dan merupakan faktor kunci dalam penyelarasan strategi dari sumber daya organisasi. Implementasi $I C$ merupakan sesuatu hal yang relatif baru di Indonesia dan dilingkungan bisnis global, akademik, pemerintahan, pengusaha, dan pemegang saham selama dekade terakhir ini. Beberapa negara maju sudah menerapkan konsep ini, contohnya Australia, Amerika, Rusia, dll. Selain itu sebelumnya belum pernah ada penggunaan istilah itangible assets dan intellectual capital yang mengacu satu set faktor yang merupakan sumber laba dalam perusahaan (MERITUM, 2001).

Puspitahati dkk. (2011) meneliti tentang pengungkapkan IC pada website perguruan tinggi negeri di Indonesia yaitu Universitas Indonesia, Institut Teknologi Bandung, dan Universitas Gadjah Mada, peneliti ini menggunakan komponen yang mengacu pada Leitner (2002), yang terdiri dari 39 item. Hasil penelitian menunjukkan bahwa praktik pengungkapan intellectual capital pada official website tergolong rendah. Hal ini bisa dibuktikan dengan total pengungkapan komponen di universitas belum ada yang mencapai skor maksimal, prosentase pengungkapan tertinggi belum mencapai $50 \%$ dari jumlah item IC universitas. Selain itu, di setiap komponen belum menunjukkan pemerataan. Banyak komponen yang belum diungkapkan oleh tiga perguruan tinggi negeri di Indonesia.

Bezhani (2010) meneliti pada 119 universitas di Inggris yang terdaftar di The Sunday Times University Guide 2006 di situs web "TIMES" dengan menggunakan framework Intellectual Capital untuk universitas di Eropa. Hasilnya, pada kategori human capital, tertinggi adalah akademik dan staf penelitian. Structural capital terbanyak mengungkapkan tentang investasi dalam perpustakaan, dan relational capital paling banyak pengungkapannya adalah kerjasama mitra baru dan konferensi yang diselenggarakan.

Penelitian ini mengukur pengungkapan intellectual capital pada website universitas peraih QS-Star pada September 2011. QS-Star rating system dirancang untuk merespon kebutuhan lembaga yang membutuhkan evaluasi dalam menilai semua kekuatan mereka, menggunakan indikator yang lebih komprehensif selain yang digunakan dalam peringkat lain. QS-Star membantu calon mahasiswa untuk proses pengambilan keputusan dalam memilih universitas. Ini memberikan siswa dengan wawasan yang lebih dalam, memungkinkan mereka untuk melihat dan mengidentifikasi keunggulan-keunggulan yang ada pada suatu universitas. Misi QS adalah membuat orang termotivasi untuk memenuhi potensi mereka dengan mendorong pencapaian pendidikan, mobilitas internasional dan pengembangan karir.

Penelitian ini menggunakan komponen IC universitas, yang dikonstruksi oleh Ulum (2011) yang merupakan modifikasi dari Leitner (2002). Modifikasi tersebut dilakukan dengan mempertimbangkan standart pendidikan tinggi di Indonesia yang sebagaimana diatur pada standart akreditasi program studi Badan Akreditasi Nasional Perguruan Tinggi (BAN-PT). Rumusan masalah yang diajukan dalam penelitian ini adalah: Bagaimana Praktik Pengungkapan IC pada Website Universitas Peraih QS-Star 2011 di Indonesia?

\section{METODE PENELITIAN}

\section{Jenis Penelitian}

Jenis Penelitian ini termasuk penelitian deskriptif, dimana penelitian ini menggambarkan atau menjelaskan suatu fenomena secara sistematis dan akurat 
mengenai fakta-fakta, sifat-sifat dan hubungan antara komponen-komponen yang diteliti.

\section{Objek Penelitian}

Objek penelitan pada penelitian ini adalah 35 perguruan tinggi peraih $Q S$ Star pada September 2011. QS-Star merupakan suatu sistem evaluasi yang menilai universitas di seluruh dunia dengan menggunakan metode rating. Universitas diberi rating bintang satu sampai dengan bintang lima sesuai dengan kinerja universitas dalam evaluasi. Kaitannya dengan penelitian ini, peneliti menganggap evaluasi kinerja yang dilkakukan oleh QS-Star memungkinkan adanya unsur pengungkapan IC pada web universitas tersebut.

\section{Jenis dan Sumber Data}

Jenis data pada penelitian ini adalah data tentang informasi pengungkapan intellectual capital pada website universitas peraih QS-Star. Menurut sumbernya, data yang digunakan untuk mendukung penelitian ini adalah data sekunder, dimana data tersebut diperoleh secara tidak langsung melalui pencatatan yang sudah ada.

\section{Teknik Perolehan Data}

Teknik perolehan data pada penelitian ini menggunakan dokumentasi, dimana data diperoleh dari official website universitas yang menjadi objek penelitian.

\section{Unit Analisis}

Unit analisis pada penelitian ini adalah 35 website universitas peraih $Q S$ Star pada September 2011.

\section{Tahapan Analisis Data}

Tahapan analisis data yang dilakukan pada penelitian ini adalah sebagai berikut:

1. Mencari data intellectual capital di official website 35 universitas peraih $Q S$ Star.

2. Mengklasifikasikan informasi intellectual capital ke dalam sub-kategori human capital, structural capital, dan relational capital dengan menggunakan komponen IC yang dikonstruksi oleh Ulum (2011) yang merupakan modifikasi dari Leitner (2002) yang terdiri dari 46 item.

3. Memberi tanda check list dan nilai pada informasi intellectual capital jika terdapat satu item yang diungkapkan maka akan mendapakan skor "1" jika tidak " 0 ".

4. Melakukan perhitungan berapa jumlah informasi yang telah diungkapkan oleh universitas.

5. Melakukan analisis deskriptif pada tiga kategori yang terdiri dari beberapa item, yaitu: human capital, relational capital, dan structural capital.

\section{HASIL PENELITIAN}

\section{Pengungkapan Intellectual Capital pada Website Universitas Peraih QS-Stars}

Dalam penelitian ini, praktik pengungkapan intellectual capital dikelompokkan menjadi tiga komponen yang dimodifikasi dari Badan Akreditasi Nasional Universitas (BAN-PT) dan Leitner (2002) yang dikonstruksi oleh Ulum (2011), komponen tersebut antara lain human capital, relational capital, dan sructural capital yang didalamnya terdapat 46 item. 
Analisis

Praktik...

326

Tabel 1

Jumlah

Pengungkapan dan

Peringkat

Pengungkapan Item
Penggalian data dilakukan selama 15 hari terhitung mulai 11 Desember 2011 hingga 26 Desember 2011. Pengunjungan website dari masing-masing universitas mencapai dua hingga tiga kali. Secara keseluruhan objek yang diteliti mengungkapkan tiga komponen yang dianalisis, namun masih banyak universitas yang belum mengungkapkan item-item di dalam komponen tersebut. Dari 35 universitas peraih QS-Star, hanya 34 website yang dapat diakses selama masa pencarian data, website Universitas Jember tidak dapat diakses, sehingga objek penelitian menjadi 34 universitas.

Pada saat pencarian data, masih banyak terdapat informasi yang tidak up to date dari website universitas. Hasil tersebut bisa juga dikarenakan belum banyaknya pihak internal yang peduli akan pentingnya informasi. Sejalan dengan lahirnya undang-undang nomor 14 tahun 2008 tentang Keterbukaan Informasi Publik (KIP), maka layak menjadi pertimbangan untuk 'meregulasikan' bahwa (setidaknya) PTN diwajibkan untuk secara rutin setiap tahun menyampaikan laporan tahunan. PTS juga sesungguhnya jauh lebih berkepentingan untuk membuat dan menyajikan laporan tahunan untuk kepentingan jangka panjang.

Selain itu, pembuatan laporan tahunan oleh universitas di Indonesia masih sangat jarang. Padahal, di beberapa negara (misalnya di Eropa, Australia, dan Singapura), universitasnya telah melahirkan laporan tahunan secara rutin, setiap tahun, yang dapat diakses melalui website resmi universitas. Informasi yang disajikan dalam laporan tahunan bisa lebih akurat dan traceable dibandingkan informasi yang terpampang di website universitas. Laporan tahunan biasanya disajikan dalam format pdf sehingga lebih 'mapan' sebagai sebuah informasi yang tidak berubah-ubah sebagaimana informasi dalam website yang setiap saat bisa berganti. Namun untuk mendapatkan informasi pada laporan tahunan, sangat sulit karena jarang universitas meng- update informasi tersebut di media. Sehingga memperdayakan website dengan meng-update informasi merupakan cara untuk menarik stakeholders serta menarik calon mahasiswa untuk bergabung di universitas tersebut.

\section{PEMBAHASAN}

Berikut ringkasan hasil dari analisis data dengan menggunakan content analysis yang diringkas berdasarkan jumlah item yang diungkapkan berdasarkan tiga komponen yang dianalisis, dan di urutkan berdasarkan urutan tertinggi universitas yang mengungkapkan 46 item.

\begin{tabular}{|c|c|c|c|c|c|c|}
\hline \multirow[b]{2}{*}{ No } & \multirow[b]{2}{*}{ Nama Universitas } & \multicolumn{3}{|c|}{ Jumlah Pengungkapan Komponen } & \multirow[b]{2}{*}{ Jumlah } & \multirow[b]{2}{*}{$\%$} \\
\hline & & $\begin{array}{l}\text { Human } \\
\text { Capital }\end{array}$ & $\begin{array}{l}\text { Structural } \\
\text { Capital }\end{array}$ & $\begin{array}{c}\text { Relational } \\
\text { Capital }\end{array}$ & & \\
\hline 1 & Universitas Airlangga & 87 & 2315 & 1511 & 33 & 72 \\
\hline 2 & $\begin{array}{l}\text { Institut Teknologi Sepuluh } \\
\text { Nopember }\end{array}$ & 88 & 2311 & 1513 & 32 & 69 \\
\hline \multirow{2}{*}{3} & Universitas Muhammadiyah & & & & & \\
\hline & Malang & 88 & 2315 & 159 & 32 & 69 \\
\hline 4 & Universitas Brawijaya & 86 & 2313 & 1512 & 31 & 67 \\
\hline 5 & Universitas Sebelas Maret & 86 & 2312 & 1513 & 31 & 67 \\
\hline 6 & Universitas Diponegoro & 86 & 2313 & 159 & 28 & 61 \\
\hline 7 & Institut Teknologi Bandung & 88 & 2310 & 159 & 27 & 59 \\
\hline 8 & Universitas Syiah Kuala & 87 & 239 & 159 & 25 & 54 \\
\hline 9 & Universitas Jenderal Soedirman & 85 & 2311 & 158 & 24 & 52 \\
\hline 10 & Universitas Pendidikan Indonesia & 87 & 2310 & 157 & 24 & 52 \\
\hline 11 & Universitas Sriwijaya & 86 & 2311 & 156 & 23 & 50 \\
\hline 12 & Universitas Kristen Petra & 85 & 2311 & 157 & 23 & 50 \\
\hline
\end{tabular}




\begin{tabular}{|c|c|c|c|c|c|c|}
\hline \multirow[b]{2}{*}{ No } & \multirow[b]{2}{*}{ Nama Universitas } & \multicolumn{3}{|c|}{ Jumlah Pengungkapan Komponen } & \multirow[b]{2}{*}{ Jumlah } & \multirow[b]{2}{*}{$\%$} \\
\hline & & $\begin{array}{l}\text { Human } \\
\text { Capital }\end{array}$ & $\begin{array}{c}\text { Structural } \\
\text { Capital }\end{array}$ & $\begin{array}{c}\text { Relational } \\
\text { Capital }\end{array}$ & & \\
\hline 13 & Universitas Bina Nusantara & 82 & 237 & 1512 & 21 & 46 \\
\hline 14 & Universitas Padjadjaran & 87 & 237 & 158 & 22 & 48 \\
\hline 15 & Universitas Hasanuddin & 84 & 239 & 159 & 22 & 48 \\
\hline 16 & Universitas Islam Indonesia & 83 & 2310 & 159 & 22 & 48 \\
\hline 17 & Universitas Negeri Yogyakarta & 86 & 239 & 156 & 21 & 46 \\
\hline 18 & Universitas Parahyangan Catholic & 85 & 238 & 157 & 20 & 43 \\
\hline 19 & Universitas Negeri Malang & 86 & 236 & 158 & 20 & 43 \\
\hline 20 & STSI Bandung & 85 & 2310 & 155 & 20 & 43 \\
\hline 21 & Institut Pertanian Bogor & 82 & 239 & 158 & 19 & 41 \\
\hline 22 & Universitas Ahmad Dahlan & 85 & 238 & 155 & 18 & 39 \\
\hline \multirow{2}{*}{23} & Universitas Muhammadiyah & & & & & \\
\hline & Surakarta & 83 & 2310 & 155 & 18 & 39 \\
\hline 24 & Universitas Lampung & 85 & 237 & 156 & 18 & 39 \\
\hline 25 & Universitas Negeri Makassar & 84 & 238 & 156 & 18 & 39 \\
\hline 26 & Universitas Udayana & 84 & 236 & 157 & 17 & 37 \\
\hline 27 & Universitas Andalas & 84 & 238 & 155 & 17 & 37 \\
\hline 28 & Universitas Atma Jaya Yogyakarta & 81 & 235 & 1510 & 16 & 35 \\
\hline 29 & Universitas Pasundan & 84 & 238 & 154 & 16 & 35 \\
\hline 30 & Universitas Sanata Dharma & 84 & 335 & 157 & 16 & 35 \\
\hline 31 & Universitas Gunadarma & 81 & 239 & 156 & 16 & 35 \\
\hline 32 & Universitas Nasional & 82 & 236 & 158 & 16 & 35 \\
\hline 33 & Universitas Negeri Gorontalo & 82 & 236 & 154 & 12 & 26 \\
\hline \multirow{3}{*}{34} & Institut Teknologi Nasional & & & & & \\
\hline & Bandung & 82 & 237 & 153 & 12 & 26 \\
\hline & Jumlah & 160 & 309 & 261 & 730 & \\
\hline
\end{tabular}

Dari tabel 1 terlihat Universitas Airlangga (UNAIR) paling banyak mengungkapkan jumlah item yang dianalisis, hampir setengah dari item yang diungka pkan yaitu 33 item dari 46 item, sehingga prosentase pengungkapannya sebesar $76 \%$. Jumlah pengungkapan item terendah ada pada Universitas Teknologi Nasional Bandung (ITENAS) dan Universitas Negeri Gorontalo (UNG) yang mengungkapkan 26 item, sehingga prosentasenya kurang dari 50\% yaitu hanya $26 \%$.

\section{HUMAN CAPITAL}

Pada komponen ini merupakan kompetensi potensial yang dimiliki oleh masing-masing universitas, dimana pada komponen ini dijelaskan mengenai jumlah profesor, dosen, staf dan jumlah yang prestasi yang dimiliki dosen. Pada komponen ini beberapa universitas secara penuh mengungkapkan delapan item pada komponen human capital.

Jumlah pengungkapan item pada human capital terbanyak dari 34 objek penelitian adalah jumlah staf non akademik yaitu sebanyak 28 universitas yang melaporkan sehingga prosentasenya mencapai $80 \%$. Sedangkan jumlah pengungkapan item dosen tetap sebanyak 27 item dengan prosentase 77\%. Jumlah pengungkapan dua item ini sangat berbanding terbalik dimana seharusnya jumlah item pada dosen tetap lebih tinggi dibanding staf non akademik, karena dosen merupakan human yang sangat berpengaruh besar terhadap output (alumni) yang dihasilkan oleh universitas. 
Analisis

Praktik...

Pengungkapan item terendah pada komponen human capital adalah item jumlah dosen tidak tetap. Dari 34 universitas hanya tujuh universitas yang mengungkapkan item ini sehingga prosentase pengunkapan item ini hanya 20\%, $80 \%$ universitas yang tidak mengungkapkan hanya menyajikan nama-nama dosen akademik saja, namun tidak dibedakan dosen tetap dan tidak tetap.

Institut Teknologi Sepuluh November (ITS), Institut Teknologi Bandung (ITB) dan Universitas Muhammadiyah Malang (UMM) merupakan universitas yang secara penuh mengungkapkan delapan item. Dari ketiga perguruan tinggi tersebut, dua diantaranya merupakan universitas negeri, sedangkan UMM, universitas swasta. Universitas yang terendah dalam pengungkapan komponen ini adalah Universitas Gunadarma dan Universitas Atma Jaya, yang hanya mengungkapkan satu item dari delapan item yang dianalisis. Item yang diungkapkan dua universitas tersebut juga berbeda, Universitas Atma Jaya mengungkapkan item jumlah staf non akademik, sedangkan Universitas Atma Jaya mengungkapkan jumlah dan jenis pelatihan.

\section{STRUCTURAL CAPITAL}

Pada komponen ini terdapat empat kategori terpisah, seperti structural capital yang menjelaskan mengenai perpustakaan, lisensi dan layanan laboratorium; selanjutnya budaya organisasi yang didalamnya terdapat empat item seperti, visi, misi, tujuan dan strategi pencapaian universitas. Ketiga merupakan sistem pembelajaran dan pengajaran dimana item ini terdiri dari tata cara pembelajaran dari teknik, sistem pembelajaran, sistem perwalian hingga masa studi sampai rasio drop out mahasiswa. Keempat yaitu sistem pembimbingan tugas akhir.

\section{STRUCTURAL CAPITAL}

Pada kategori ini terdapat investasi di perpustakaan electronic, jumlah dan penghasilan dari lisensi, serta layanan laboratorium. Pengungkapan terbesar pada kategori ini adalah layanan laboratorium, karena laboratorium merupakan fasilitas yang ditawarkan oleh setiap universitas dan laboratorium merupakan sarana penunjang dalam pelaksanaan belajar-mengajar. Sehingga hampir keseluruhan universitas mengungkapkannya. Untuk mempermudah layanan bagi mahasiswa dan dosen dalam pemenuhan kebutuhan literatur bagi mereka, sebagian universitas tepatnya $77 \%$ universitas yang mengungkapkan item ini.

Dari 34 universitas, hanya 12 universitas yang melaporkan jumlah lisensi yang dimiliki. Lisensi sendiri merupakan aset tambahan yang dimiliki universitas karena dari lisensi dapat menghasilkan dana tambahan bagi universitas, namun dalam pengungkapan penghasilan lisensi, tidak ada satupun universitas yang mempublikaikannya. Biasanya penghasilan ini dipublikasi dalam laporan tahunan yang dilaporkan pertahun oleh universitas.

\section{Budaya Organisasi}

Dalam kategori budaya organisasi hampir seluruh universitas melaporkannya, karena pada kategori ini terdapat empat item yang wajib dimiliki oleh setiap perguruang tinggi, seperti visi, misi, tujuan dan strategi pencapaian. Visimisi paling banyak diungkapkan, untuk tujuan dan strategi universitas jarang mengungkapkannya. Pada kategori ini terdapat satu universitas yang tidak mengungkapkan pada website mengenai visi-misi universitas, yaitu Universitas Padjajaran, dimana universitas ini hanya mengungkapkan visi-misi pada setiap jurusan sehingga tidak termasuk dalam item ini. 
Pada kategori sistem pembelajaran dan pengajaran yang paling banyak diungkapkan oleh universitas adalah item sarana dan prasaran, 32 universitas melaporkan item ini, dua universitas yang tidak mengungkapkan yaitu Universitas Pasundan dan Universitas Andalas. Pengungkapan item ini pada website sangat jelas tujuannya, yaitu selain sebagai publikasi, tujuannya adalah untuk menarik minat pengunjung untuk memberikan nilai tawar yang lebih. Pada website pengungkapan ini sangat mudah dicari terdapat pada menu sarana dan prasarana atau fasilitas.

Jumlah dosen persiswa merupakan pengungkapan terendah, hanya satu universitas yang mengungkapkan item ini adalah Universitas Udayana. Pada item silabus dan rencana pembelajaran dari keenam universitas yang mengungkapkan, semua silabus didapatkan dari mengunduh link yang telah ada pada website, sehingga tidak ada silabus pembelajaran yang secara langsung dipublikasikan di website.

Sama halnya pada teknik pembelajaran, sistem evaluasi pembelajaran, sistem perwalian, rata-rata masa studi, dan jumlah dosen per siswa, universitas yang mengungkapkan item ini diperoleh dari file evaluasi yang diunduh dari website universitas.

Item rasio drop out di ungkapkan hanya tiga universitas, yaitu ITB, Universitas Islam Insonesia dan STSI Bandung. Sangat jarang universitas ini melaporkan karena pengungkapan ini merupakan informasi gagalnya sistem pembelajaran dan layanan bagi mahasiswa sehingga mengakibatkan mahasiswa mengundurkan diri.

\section{Sistem Pembimbingan Tugas Akhir}

Item yang paling banyak diungkapkan pada kategori ini adalah jumlah lulusan wisuda, 11 universitas yang mengungkapkan item ini. Sedangkan pada item yang terendah diungkapkan oleh universitas adalah kualifikasi dosen akademik yang hanya diungkapkan oleh dua universitas seperti Universitas Muhammadiyah Malang dan Universitas Pasundan. Dimana kualifikas ini diungkapkan pada data yang diunduh dari link yang sudah tersedia, bukan hanya informasi mengenai kualifikasi dosen akdemik, informasi mengenai ketersediaan mekanisme penulisan tugas akhir juga tersedia pada file yang terlebih dahulu harus diunduh.

Pada komponen structural capital, universitas yang tertinggi jumlah pengungkapan item adalah Universitas Airlangga dan Universitas Muhammadiyah Malang, dengan mengungkapkan jumlah item yang sama banyak yaitu 15 item. Kedua universitas itu merupakan universitas negeri dan swasta peraih $Q S$-Stars 2011.

Universitas Sanata Dharma dan Universitas Atma Jaya merupakan universitas yang hanya mengungkapkan lima item dari 23 item yang dianalisis dalam structural capital, sehingga universitas ini merupakan universitas yang paling rendah dalam pengungkapan item.

\section{RELATIONAL CAPITAL}

Kategori yang terdapat pada komponen relational capital adalah penelitian dan publikasi, knowledge transfer to public, relasi mahasiswa, dan relasi alumni. Berikut rincian dari pembahasan komponen relational capital: 
Analisis

Praktik...

330

\section{Penelitian dan publikasi}

Kategori penelitian dan publikasi menjelaskan item mengenai jenis penelitian dan jumlah publikasi penelitian yang dilakukan oleh setiap universitas. Pada kategori ini, item yang paling banyak diungkapkan oleh beberapa universitas adalah item penelitian dan pengabdian kepada masyarakat serta publikasi ilmiah di jurnal lokal yaitu 27 universitas. Item penelitian dan pengabdian pada masyarakat merupakan salah satu strategi yang dilakukan oleh universitas untuk mengaplikasikan ilmu yang dimiliki untuk membantu masyarakat. Publikasi di jurnal lokal merupakan publikasi jurnal yang dimiliki oleh setiap universitas, sehingga banyak universitas yang mengungkapkan item ini.

Item terendah pada kategori ini adalah para ilmuan internasional di universitas. Karena tidak ada universitas secara nyata mempublikasikan nama ilmuan yang dimiliki oleh setiap universitas.

\section{Knowladge transfer to public}

Hits situs internet dan E-learing merupakan item-item yang terdapat pada komponen ini. Hits situs internet merupakan jumlah pengunjung website yang mengunjungi website tersebut sehingga terdapat data rekaman mengenai angka kunjungan. Selanjutnya e-learning merupakan cara pembelajaran jarak jauh yang dimiliki oleh universitas, pengungkapan item ini merupakan pengungkapan terbanyak yang diungkapkan oleh universitas yaitu sebanayak 28 universitas yang mengungkapkannya.

\section{Relasi Mahasiswa}

Relasi mahasiswa merupakan kategori yang ditunjukkan kepada mahasiswa, dimana item-item didalamnya merupakan layanan mahasiswa dan jumlah prestasi yang dimiliki oleh mahasiswa dari sisi akademik dan minat bakat.

Dari kedua item ini, item layanan mahasiswa merupakan item terbanyak yang diungkapkan oleh 29 universitas. Sedangkan lima universitas yang tidak mengungkapakan adalah Universitas Negeri Gorontalo, Universitas Hasanudin, Universitas Islam indonesia, Universitas Petra, dan Universitas Teknologi Nasional Bandung. Pengungkapan item ini berpengaruh positif terhadap kelangsungan informasi mahasiswa, karena layanan mahasiswa secara update memberitakan informasi-informasi terbaru yang ada di unversitas yang berhubungan dengan mahasiswa.

Publikasi dalam hal prestasi yang dimiliki oleh mahasiswa merupakan sebuah bentuk penghargaan yang diberikan oleh universitas kepada mahasiswa berprestasi, selain itu publikasi ini juga menjadi nilai tawar bagi universitas karena prestasi yang dimilikinya. Pengungkapan item ini diungkapkan oleh 22 universitas peraih QS-Stars.

\section{1) Relasi Alumni}

Kategori ini merupakan kategori yang berhubungan dengan alumni, diantaranya mengenai perekaman data alumni, pemberdayaan alumni serta partisipasi alumni dalam pengembangan akademik universitas. Dengan demikian peran alumni masih sangat dibutuhkan oleh universitas.

Dari ketiga item tersebut item yang tertinggi diungkapkan oleh universitas adalah item perekaman data lulusan yaitu sebanyak 25 universitas yang melaporkannya. Adanya pengungkapan ini untuk mengetahui berapa banyak alumni yang dimiliki oleh universitas dan berapa mahasiswa yang masih belum menyelesaikan masa studinya. Perekaman data alumni juga digunakan untuk 
mengetahui pekerjaan para alumni, sehingga ini juga bisa menjadi nilai tawar untuk mempublikasikan prestasi. Selanjutnya pelayanan dan pendayagunaan lulusan diambil dari adanya lowongan pekerjaan yang ditawarkan oleh setiap universitas pada website yang dimiliki, ada 24 universitas yang mengungkapkan item ini. sedangkan item terendah adalah partisipasi lulusan dalam pengembangan akademik. Partisipasi lulusan ini dapat dilihat dari adanya kegiatan seperti seminar akademik yang dilakukan oleh alumni dan penghargaan yang didapatkan oleh alumni.

Dari keempat pengungkapan kategori tersebut, yang didalamnya terdapat 15 item yang dianalisis, Institut Teknologi Sepuluh November dan Universitas Sebelas Maret yang mengungkapkan item ini paling banyak yaitu 13 item sehingga rasio pengungkapannya mencapai $87 \%$. Universitas yang paling rendah pengungkapannya adalah Institut Teknologi Nasional Bandung yang hanya mengungkapkan 3 item dari 25 item sehingga rasio pengungkapan pada relational capital adalah $20 \%$.

\section{Catatan Akhir}

34 universitas peraih QS-Stars pada September 2011 yang jumlah pengungkapan IC terbanyak dari tiga komponen yang dianalisis adalah Universitas Airlangga, dimana rincian pengungkapan di setiap komponen adalah jumlah $h u^{-}$ man capital terdapat tujuh item, structural capital 15 item dan relational capital mencapai 11 item, sehingga jumlah pengungkapan pada Universitas Airlangga berjumlah 33 item dari 46 item intellectual capital. Universitas Airlangga merupakan universitas negeri, untuk universitas swasta yang jumlah pengungkapan intellectual capital tertinggi adalah Universitas Muhammadiya Malang yang jumlah pengungkapan itemnya sama dengan ITS yaitu 32 item selisih satu angka dari UNAIR. Jumlah pengungkapan pada komponen human capital sebanyak 8 item, 15 item untuk structural capital dan 9 item untuk relational capital.

Universitas terendah yang mengungkapkan intellectual capital adalah Institut Teknologi Nasional Bandung yang hanya mengungkapkan 12 item dari tiga kategori. Dua item yang diungkapkan pada komponen human capital, serta structural capital hanya diungkapkan tujuh item, dan tiga item yang diungkapkan pada relational capital. Selain itu Universitas Jember merupakan universitas yang pengungkapan IC nya tidak ada pada tabel 4.4 dikarenakan website Universitas Jember tidak beroperasi sehingga tidak dapat dilakukan penggalian data secara dalam mengenai pengungkapan intellectual capital.

\section{Simpulan}

Berdasarkan hasil penelitian yang telah dilakukan sebagaimana telah diungkapkan, secara umum pengungkapan IC dengan tiga komponen yang terdiri dari 46 item didalamnya dengan objek 35 universias peraih QS-Star di Indonesia, namun dari 35 universitas tersebut, website Universitas Jember tidak dapat diakses, sehingga tidak dapat dilakukan penggalian data yang diperlukan, berikut simpulan dari penelitian ini:

1. Human Capital, dari delapan item dalam komponen ini, item jumlah staf non akademik lah yang paling banyak diungkapkan oleh 28 dari 34 universitas peraih $Q S$-Stars. Sedangkan yang terendah adalah jumlah dosen tidak tetap yang hanya diungkapkan oleh tujuh universitas saja. Dari ke 34 universitas yang palling banyak mengungkapkan komponen ini adalah Institut Teknologi Sepeuluh November, Institut Teknologi Bandung dan Universitas Muhammadiyah Malang yang pengungkapannya delapan item, ini berarti keseluruhan item telah diungkapkan oleh ketiga universitas ini sedangkan 
Analisis

Praktik...

332 terendah adalah Universitas Atmajaya dan Universitas Gunadarma yang mengungkapakn satu item saja.

2. Structural Capital, item sarana dan prasarana pada komponen ini menjadi item yang terbanyak diungkapkan yaitu 32 universitas, dan item yang terendah dari 23 item pada komponen ini adalah penghasilan dari liensi tidak satupun universitas yang mengungkapkannya. Universitas yang paling banyak mengungkapkan item pada komponen ini adalah universitas Universitas Airlangga dan Universitas Muhammadiyah Malang. Universitas Sanata Dharma dan Universitas Atma Jaya merupakan universitas yang paling rendah pengungkapan pada komponen ini yaitu lima item.

3. Relational Capital, E-learning merupakan item yang paling banyak diungkapkan oleh objek yang diteliti yaitu 28 universitas yang mengungkapkannya. Sedangkan terendah adalah item jumlah penelitian pihak ke-3 hibah luar negeri yang diungkapkan oleh Universitas Airlangga. Dari 34 Universitas, Institut Teknologi Sepuluh November dan Universitas Sebelas Maret yang paling banyak mengungkapkan komponen ini yaitu 13 item dari 15 item sehingga prosentasenya $87 \%$. Institut Teknologi Nasional Bandung merupakan universitas yang paling rendah dengan tiga pengungkapan item.

4. 34 objek penelitian yang diambil dari universitas peraih $Q S$-Star, Universitas Airlangga merupakan universitas yang terbanyak pengungkapan IC nya yaitu 33 item dari 46 item yang dianalisis sehingga prosentase pengungkapannya $72 \%$. Sedangkan terendah adalah Institut Teknologi Nasional Bandung mengungkapkan 12 item dari tiga komponen yang dianalisis.

\section{Keterbatasan dan Saran}

1. Sebagaimana lazimnya penelitian yang menggunakan content analysis, potensi subjektifitas peneliti sulit terhindarkan saat melakukan check list item IC pada website. Untuk meminimalkan hal ini, mungkin dapat dilakukan check list secara berulang dan dengan melibatkan tim.

2. Penelitian ini hanya mendeskripsikan bagaimana pengungkapan intellectual capital pada official website, tidak ada dokumen pembanding, misalnya laporan tahunan seperti banyak dilakukan pada organisasi swasta. Penelitian selanjutnya dapat melakukan konfirmasi langsung kepada universitas yang menjadi objek penelitian.

3. Item dari komponen yang dianalisis merupakan modifikasi dari Lietner (2002) dan BAN-PT (Badan Akreditas Nasional-Perguruan Tinggi) yang digunakan dalam penentuan akreditasi PT, sehingga banyak ditemukan item dengan kategori jumlah, sedangkan jarang website universitas yang menampilkan jumlah, sehingga checklist dilakukan apabila ada pengungkapan item yang dimaksud walaupun tidak disebutkan jumlah.

\section{Daftar Pustaka}

Benzhani, ivoni. 2010. "Intellectual Capital Reporting at UK Universities". Jurnal of Intellectual Capital at: http//www.emeraldinsight.com/1469-1930.htm

Leitner, K.H. 2002. Intellectual capital reporting for universities: conceptual background and application within the reorganization of Ausitrian universities, paper presented at the transparent Enterprise, The value of Intangibles Conference, Autonomous University of Madrid Ministry of Economy, Madrid. 
MERITUM. 2001. "Guidelines for Managing and Reporting on Intangibles (Intellectual Capital Report), MERITUM Project, available at: www.uam.es/ meritum,com accessed Oktober 2011.

Puspitahati, A., Ulum, I., dan Prasetyo, A. 2011. "Kajian Penelitian Aktual, Bidang Ekonomi dan Bisnis Dalam Rangka Meningkatkan Kinerja Organisasi, Perusahaan, Pemberdayaan Masyarakat dan Perekonomian Nasional".Proseding; Seminar Nasional Call for Paper 2011. 9 Februari. Malang.

Ulum, Ihyaul. 2009. Intellectual Capital; Konsep dan Kajian Empiris. PT. Graha Ilmu, Yogyakarta.

Ulum, Ihyaul. 2011. "Konstruksi Komponen Intellectual Capital untuk Perguruan Tinggi di Indonesia". Penelitian Dasar Keilmuan (PDK) DPPM-UMM (Unpublished)

Zurnali, C. 2008. Membangun Universitas Berkelas Dunia. Available online at:www.modusacehnews,com accessed Oktober 2011. 
